\title{
STUDI TINGKAT KEPATUHAN MASYARAKAT PROPINSI KEPULAUAN RIAU UNTUK MELAKSANAKAN SOCIAL/PHYSICAL DISTANCING DALAM UPAYA MENCEGAH PENYEBARAN VIRUS COVID-19
}

\author{
Study Of Community Compliance Levels Of Riau Islands Province For Implementing Social / \\ Physical Distancing In Effort To Prevent Spread Of Covid-19 Virus \\ Indra Martias ${ }^{1}$, Luh Pitriyanti ${ }^{2}$,Novian Aldo ${ }^{3}$ \\ ${ }^{1}$ Poltekkes Kemenkes Tanjungpinang \\ 1,2,3Pusat Unggulan IPTEKS Kesehatan Masyarakat Wilayah Kepulauan \\ (PUI Kemilau) Poltekkes Kemenkes Tanjungpinang \\ *) indramartias@ymail.com /Hp 085263706120)
}

\begin{abstract}
The Indonesian government had intervened to suppress the spread of the increasingly massive Covid-19 virus. However, if half of the community did not conduct social / physical distancing, the number of cases and deaths would continue to grow. Riau Islands Province consists of 7 regencies / cities in the archipelago bordering directly with neighboring countries Singapore, Malaysia and Vietnam. Based on this, it was necessary to study the compliance of the people of the Riau Islands Province to carried out social / physical distancing in an effort to prevent the spread of the Covid-19 virus as the Gateway to the Republic of Indonesia. This type of research was quantitative research with a survey method. The instrument in this study was an online questionnaire using Google forms. The sample size calculation was done using the Lemeshow survey formula with a population of 970,132 people according to data on the number of productive ages, $50 \%$ anticipated population proportion and $95 \%$ confident interval. The sample size needed was as many as 384 inhabitants. The sample size calculation for each district / city was calculated by proportional to size (PPS). The results of the study show that there were $60 \%$ of non-compliant people and $40 \%$ of people who were compliant to carry out social / physical distancing in Riau Islands Province. Respondents were dominated by people living in Tanjungpinang City (40.9\%) and Batam City (26.7\%). Most of the respondents' education came from tertiary institutions (51.7\%). The access to information about covid-19 was obtained mostly from social media (93.5\%). There were still many people who did not comply with the government's call to implement social / physical distancing. Decisive steps were needed from the government, especially the Riau Islands Province government. This was not meant to be an appeal anymore but an order that must be carried out by all the people of the Riau Archipelago Province.
\end{abstract}

Keywords : compliance, social/physical distancing, covid-19

\section{ABSTRAK}

Pemerintah Indonesia sudah melakukan intervensi untuk menekan penyebaran virus Covid-19 yang semakin masif. Namun, bila setengah dari masyarakat tidak melakukan social/physical distancing maka jumlah kasus dan kematian akan terus bertambah. Propinsi Kepulauan Riau terdiri atas 7 kabupaten/kota kepulauan yang berbatasan langsung dengan negara tetangga Singapura, Malaysia dan Vietnam. Berdasarkan hal tersebut perlu dilakukan studi tentang kepatuhan masyarakat Propinsi Kepulauan Riau untuk melaksanakan social/physical distancing dalam upaya mencegah penyebaran virus Covid-19 sebagai Pintu Gerbang Negara Republik Indonesia. Jenis penelitian yang dilakukan adalah penelitian kuantitatif dengan metode survei. Instrumen dalam penelitian ini adalah kuesioner online dengan menggunakan google form. Perhitungan besar sampel dilakukan menggunakan rumus survei Lemeshow dengan jumlah populasi 970.132 jiwa sesuai dengan data jumlah usia produktif, anticipated population proportion $50 \%$ dan confident interval 95\%. Besar sampel yang diperlukan adalah sebanyak 384 jiwa. Perhitungan besar sampel untuk masing-masing kabupaten/kota dihitung dengan proportional to size (PPS). Hasil penelitian menunjukkan bahwa ada $60 \%$ masyarakat yang tidak patuh dan $40 \%$ masyarakat yang patuh untuk melaksanakan social/physical distancing di Propinsi Kepulauan Riau. Responden didominasi oleh masyarakat yang tinggal di Kota Tanjungpinang (40,9\%) dan Kota Batam $(26,7 \%)$. Pendidikan responden paling banyak berasal dari perguruan tinggi $(51,7 \%)$. Adapun akses informasi tentang covid-19 diperoleh paling banyak berasal dari media sosial (93,5\%). Masih banyak masyarakat yang tidak patuh terhadap himbauan pemerintah untuk melaksanakan social/physical distancing. Dibutuhkan langkah tegas dari pemerintah khususnya pemerintah Propinsi Kepulauan Riau. Hal ini dimaknai bukan himbauan lagi tapi perintah yang harus dilaksanakan oleh segenap masyarakat Propinsi kepulauan Riau.

Kata kunci : tingkat kepatuhan, social/physical distancing, covid-19

\section{PENDAHULUAN}

Status

pandemi global virus corona/covid-19 telah ditetapkan WHO pada tangga 12 Maret 2020. Dengan naiknya status corona/covid 19 menjadi pandemi ini, WHO berharap negara-negara di dunia bisa melakukan penanganan secara ekstra. Laporan WHO terakhir menyebutkan covid-19 telah menginfeksi $+1,9$ juta penduduk dunia dan jumlah yang meninggal +120 ribu jiwa termasuk di Indonesia (WHO, 2020).
Pemerintah Indonesia sudah melakukan intervensi untuk menekan penyebaran virus Covid-19 yang semakin masif. Namun, bila setengah dari masyarakat tidak melakukan social/physical distancing maka jumlah kasus dan kematian akan terus bertambah (Yanti et al., 2020). Melalui Undang-undang Nomor 8 tahun 2018 tentang Kekarantinaan Kesehatan kemudian diturunkan melalui Peraturan Menteri Kesehatan Nomor 9 tahun 2020 tentang 
Pedoman Pembatasan Sosial Berskala Besar Dalam Rangka Percepatan Penanganan Corona Virus Disease 2019 (COVID-19) merupakan salah satu upaya pemerintah untuk menekan jumlah kasus dan/atau jumlah kematian agar tidak semakin meningkat dan meluas lintas wilayah dan lintas negara dan akan berdampak pada aspek politik, ekonomi, sosial, budaya, pertahanan dan keamanan, serta kesejahteraan masyarakat di Indonesia (Kemenkes RI, 2020) .

Seruan pemerintah untuk melakukan social/physical distancing kepada masyarakat Indonesia khususnya Propinsi Kepulauan Riau dalam bentuk bekerja, belajar, dan beribadah di rumah. Tujuannya mengurangi penyebaran Covid-19. Bentuk nyata physycal distancing juga terlihat dari simbol-simbol pembatas jarak aman pada berbagai tempat umum seperti bank, pasar, restoran dan lainlain termasuk berbagai moda transportasi umum. Berdasarkan hal tersebut di atas perlu dilakukan kajian tentang "Bagaimana tingkat kepatuhan masyarakat untuk melaksanakan social/physical distance dalam upaya mencegah penyebaran virus Covid-19?".

\section{METODE}

\section{Desain, tempat dan waktu}

Penelitian ini merupakan penelitian kuantitatif dengan metoda survei. Penelitian ini dilaksanakan pada tanggal 21 -29 April 2020. Lokasi penelitian dilaksanakan pada 7 kabupaten/kota yang ada di Provinsi Kepulauan Riau.

\section{Populasi dan Sampel}

Perhitungan besar sampel dilakukan dengan rumus survei dari Lemeshow dengan jumlah populasi 970.132 jiwa sesuai dengan data jumlah usia produktif dalam Kepulauan Riau Dalam Angka Tahun 2019 (BPS, 2020). Anticipated population proportion $50 \%$ dan confident interval $95 \%$. Besar sampel yang diperlukan adalah sebanyak 384 jiwa. Peneliti menetapkan jumlah minimal sampel yang diperlukan 400. Perhitungan besar sampel untuk masing-masing kabupaten/kota dihitung dengan proportional to size (PPS) sehingga didapatkan jumlah sampel untuk masingmasing kabupaten/kota adalah sebagai berikut : Kabupaten Karimun 43 jiwa, Kabupaten Bintan 29 jiwa, Kabupaten Natuna 15 jiwa, Kabupaaten Lingga 18 jiwa, Kabupaten Kepulauan Anambas 9 jiwa, Kota Batam 250 jiwa dan Kota Tanjungpinang 39 jiwa.

\section{Instrumen dan varibel penelitian}

Instrumen penelitian menggunakan kuesioner online dengan menggunakan google form. Variabel tingkat kepatuhan masyarakat yang digunakan adalah (1) pergi ke pusat keramaian (2) tidak Jaga Jarak 1,5 m (3) menggunakan transport umum (4) tidak enggunakan masker (5) berjabat tangan (6) makan diluar rumah.

\section{Pengolahan dan analisis data}

Pengolahan dan Analisis Data Data yang diperoleh berdasarkan google form yang telah diisi oleh responden kemudian diolah dengan menggunakan komputer. Data dianalisis menggunakan perangkat SPSS dan dilakukan analisis univariate yang selanjutnya disajikan dengan tabel distribusi frekuensi.

\section{HASIL}

Tabel 1. Distribusi Frekuensi Karakteristik Subjek

\begin{tabular}{lcc}
\hline \multirow{2}{*}{ Karakteristik } & \multicolumn{2}{c}{ Subjek (n) } \\
\cline { 2 - 3 } & $\mathrm{N}$ & $\%$ \\
\hline Kabupaten/kota & & \\
\hline Kab. Karimun & 113 & 11,6 \\
Kab. Bintan & 126 & 12,9 \\
Kab. Natuna & 14 & 1,4 \\
Kab. Lingga & 50 & 5,1 \\
Kab. Kep. Anambas & 13 & 1,3 \\
Kota Batam & 260 & 26,7 \\
Kota Tanjungpinang & 399 & 40,9 \\
\hline Jenis Kelamin & & \\
Responden & & \\
\hline Laki-laki & 381 & 39,1 \\
Perempuan & 594 & 60,9 \\
\hline Kelompok Umur & & \\
\hline 18-20 & 380 & 39 \\
21-30 & 304 & 31,2 \\
31-40 & 151 & 15,5 \\
$41-50$ & 103 & 10,6 \\
$>51$ & 37 & 3,8 \\
\hline Pekerjaan & & \\
\hline
\end{tabular}




\begin{tabular}{|c|c|c|}
\hline Pelajar/mahasiswa & 463 & 47,5 \\
\hline PNS/ASN & 229 & 23,5 \\
\hline Pegawai swasta & 141 & 14,5 \\
\hline Wiraswasta & 58 & 5,9 \\
\hline Honorer & 44 & 4,5 \\
\hline Pegawai & 18 & 1,8 \\
\hline BUMN/BUMD & & \\
\hline $\begin{array}{l}\text { Ibu rumah } \\
\text { tangga/lainnya }\end{array}$ & 22 & 2,3 \\
\hline Pendidikan & & \\
\hline SD & 2 & 0,2 \\
\hline SMP & 8 & 0,8 \\
\hline SMA & 461 & 47,3 \\
\hline Perguruan tinggi & 504 & 51,7 \\
\hline Jumlah & 975 & 100 \\
\hline
\end{tabular}

Tabel 2. Gambaran Sumber Informasi Mengenai COVID-19

\begin{tabular}{ccc}
\hline Sumber Informasi & Jumlah & $\begin{array}{c}\text { Persentase } \\
(\%)\end{array}$ \\
\hline Televisi & 806 & $28,48 \%$ \\
Radio & 183 & $6,47 \%$ \\
Media Sosial & 929 & $32,83 \%$ \\
Surat kabar/koran & 283 & $10,00 \%$ \\
Petugas kesehatan & 385 & $13,60 \%$ \\
RT/RW & 194 & $6,85 \%$ \\
Lainnya & 50 & $1,77 \%$ \\
\hline Jumlah & 2.830 & $100 \%$ \\
\hline
\end{tabular}

Tabel 3. Gambaran Tingkat Kepatuhan Penerapan Physical Distancing

\begin{tabular}{ccc}
\hline $\begin{array}{c}\text { Tingkat } \\
\text { Kepatuhan }\end{array}$ & Jumlah & $\begin{array}{c}\text { Persentas } \\
\text { e (\%) }\end{array}$ \\
\hline $\begin{array}{c}\text { Patuh } \\
\text { Tidak patuh }\end{array}$ & 584 & $59,9 \%$ \\
\hline Total & 975 & $40,1 \%$ \\
\hline
\end{tabular}

\section{PEMBAHASAN}

Berdasarkan tabel 1 ,responden paling banyak merupakan warga Kota Tanjungpinang dan Kota Batam. Hal ini dikarenakan Kota Tanjunginang dan Kota Batam merupakan dua kota dengan jumlah penduduk yang banyak dibandingkan kabupaten lainnya di Provinsi Kepullauan Riau. Responden pada penelitian ini didominasi oleh kelompok umur muda yaitu 18 - 20 tahun dan $21-30$ tahun. Hal ini dapat dikarenakan responden pada penelitian ini memang paling banyak merupakan pelajar dan mahasiswa.

Berbagai upaya preventif dilakukan pemerintah pusat maupun daerah untuk menanggulangi penyebaran COVID-19 di Indonesia. Langkah cepat yang dapat dikerjakan dalam menekan penyebaran COVID-19 adalah dengan menjaga anggota keluarga dan memberikan informasi-informasi penting mengenai COVID-19 (Ayu Kurniawati et al., 2020). Salah satunya adalah meningkatkan penyebaran informasi dan edukasi melalui berbagai media komunikasi. Dari data yang dikumpulkan terlihat bahwa sebagian besar responden mengakses informasi mengenai COVID-19 dari sosial media. Media sosial dapat memberikan informasi tindakan apa saja yang dapat dilakukan untuk mencegah penularan Covid19. Intervensi internet dan informatika perilaku memiliki kemampuan untuk membantu individu baik pasien suspect COVID-19 dan masyarakat umum dalam memodifikasi perilaku untuk meningkatkan kesehatan fisik, mental maupun perilaku (Sampurno et al., 2020)

Pada penelitian ini, penilaian kepatuhan dalam penerapan physical distancing dinilai dari apakah responden menjaga jarak dengan orang lain, bepergian ke pusat keramaian, menggunakan transportasi umum, menggunakan masker, berjabat tangan dengan orang lain dan makan keluar rumah (warung makan atau restaurant) ketika masa penerapan physical distancing diterapkan di Indonesia. Hasil tingkat kepatuhan masyarakat menunjukkan bahwa $59,9 \%$ masyarakat telah mematuhi protokol kesehatan untuk mematuhi kebijakan physical distancing. Hasil penelitian ini menunjukkan bahwa tingkat kepatuhan masyarkat sudah cukup baik. Namun untuk menekan penularan COVID-19, tingkat kepatuhan menerapkan physical distancing masih perlu ditingkatkan kembali mengingat wilayah Provinsi Kepulauan Riau merupakan jalur lintas 
perbatasan Indonesia dengan negara lain. Penelitian mengenai tingkat kepatuhan masyarakat dalam melakukan upaya pencegahan Covid-19 juga dilakukan di Ngronggah, Jawa Tengah khususnya mengenai kepatuhan masyarakat dalam menggunakan masker yang menunjukkan hasil bahwa sebagian besar masyarakat telah patuh menggunakan masker yaitu sebanyak 46 responden (74,19\%) (Sari, 2017). Penelitian serupa juga dilakukan pada mahasiswa STIA Muhammadiyah Selong dimana hasilnya menunjukkan bahwa penerapan social distancing dan physical distancing belum maksimal. Hal ini dapat dilihat dari persentase mahasiswa yang selalu menghindari berkumpul dan menjaga jarak hanya sebesar $49,6 \%$. Pada penerapan perilaku hidup bersih mahasiswa selama di rumah, sudah sangat baik dimana hal ini terlihat dari jumlah mahasiswa yang selalu menggunakan masker yaitu $88,9 \%$, mencuci tangan pakai sabun $96,6 \%$ dan selalu membawa handsanitizer 49,6\% (Yuniarti \& Hartati, 2020).

Kepatuhan merupakan istilah yang digunakan untuk menjelaskan perilaku masyarakat dalam menerapkan kebijakan physical distancing. Banyak faktor yang dapat mempengaruhi kepatuhan masyarakat, termasuk pengetahuan, motivasi, persepsi, keyakinan terhadap upaya pengontrolan dan pencegahan penyakit, variabel lingkungan, kualitas instruksi kesehatan, dan kemampuan mengakses sumber yang ada (Sinuraya et al., 2020). Secara peraturan perundang- undangan, Indonesia sudah memiliki peraturan perundang-undnagan yang mengatur penanggulangan dalam menangani bencana. Pemerintah sudah berusaha menerapkan peraturan perundang-undnagan yang berlaku dengan upaya preventif. Sosialisasi melalui berbagai saluran media dilakukan dalam rangka mengantisipasi masalah-masalah yang bisa terjadi saat bencana nasional non alam pandemic COVID-19 (Setyawati, 2020).

\section{KESIMPULAN}

Tingkat kepatuhan masyarakat Provinsi Kepulauan Riau dalam menerapkan physical distancing mencapai (59,9\%). Tingkat kepatuhan masyarakat ini sudah cukup baik pada masa awal pandemi namun masih perlu ditingkatkan agar perilaku pencegahan masyarkat terhadap COVID-19 lebih berjalan secara optimal.

\section{SARAN}

Peneliti selanjutnya diharapkan dapat mengukur faktor apa saja yang mempengaruhi tingkat kepatuhan masyarakat dalam penerapan physical distancing sehingga dapat memberikan masukkan bagi pemerintah dalam mengambil kebijakan.

Dibutuhkan langkah tegas dari pemerintah Propinsi Kepulauan Riau untuk menerapkan adaptasi kebiasaan baru. Hal ini dimaknai bukan hanya himbauan tapi berupa sanksi tegas bagi yang tidak melaksanakan protokol kesehatan.

\section{DAFTAR PUSTAKA}

Ayu Kurniawati, K. R., Santosa, F. H., \& Bahri, S. (2020). Sosialisasi Hidup Sehat di Tengah Wabah Virus Corona. JPMB : Jurnal Pemberdayaan Masyarakat Berkarakter, 3(1), 58-65. https://doi.org/10.36765/jpmb.v3i1.225

BPS. (2020). Kota Tanjungpinang Dalam Angka 2020. https://doi.org/1102001.2172

Kemenkes RI. (2020). Peraturan Menteri Kesehatan Republik Indonesia Nomor 9 Tahun 2020 tentang Pedoman Pembatasan Sosial Berskala Besar dalam Percepatan Penanganan Corona Virus Disease (COVID-19).

Sampurno, M. B. T., Kusumandyoko, T. C., \& Islam, M. A. (2020). Budaya Media Sosial, Edukasi Masyarakat, dan Pandemi COVID-19. SALAM: Jurnal Sosial Dan Budaya Syar-I, 7(5). https://doi.org/10.15408/sjsbs.v7i5.15210

Sari, T. F. (2017). Pengaruh Dimensi Komunitas Merek Terhadap Word Of Moutt Pada Rokok Elektrik (Vapor) Merek Tesla Invader di Bandar Lampung (Studi Pada Komunitas Vape Squad Lampung). Universitas Lampung.

Setyawati, N. (2020). Implementasi Sanksi Pidana Bagi Masyarakat Yang Beraktifitas Di Luar Rumah Saat Terjadinya Pandemi COVID-19. Jurnal Education and Development Institut Pendidikan Tapanuli Selatan, 8(2), 135-140.

Sinuraya, R. K., Abdulah, R., \& Koyama, H. (2020). Knowledge , Attitude , and Practice During the COVID-19 Pandemic : A Review. 
Jurnal Sulolipu : Media Komunikasi Sivitas Akademika dan Masyarakat Vol. 20 No.2 2020

e-issn : 2622-6960, p-issn : 0854-624X

WHO. (2020). Coronavirus Disease (COVID-19) Situation Report-209 (Issue August).

Yanti, E., Fridalni, N., \& Harmawati. (2020). Mencegah Penularan Virus Corona. Jurnal Abdimas Saintika, 2, 33-39.

Yuniarti, R., \& Hartati, W. (2020). Pemantauan Penyebaran Virus COVID-19 Pada Mahasiswa STIA Muhammadiyah Selong Menggunakan Aplikasi Google Form. 